\title{
ANALISIS KETERSEDIAAN LAHAN UNTUK TEMPAT PEMAKAMAN UMUM (Studi Kasus Tempat Pemakaman Umum Semper, Kelurahan Semper Timur, Kecamatan Cilincing, Kota Administrasi Jakarta Utara)
}

\author{
Divyana Sudiro, Suhardjo, Ode Sofyan Hardi
}

Program Studi Pendidikan Geografi, Universitas Negeri Jakarta, Indonesia

\begin{abstract}
Abstrak: Penelitian ini bertujuan untuk mengetahui tentang ketersediaan lahan pemakaman di Tempat Pemakaman Umum (TPU) Semper untuk memenuhi kebutuhan pemakaman. Metode yang digunakan adalah metode deskriptif dengan pendekatan survei. Informasi lain diperoleh dari informan dalam pengumpulan data primer. Informan tersebut adalah Pengelola TPU Semper. Teknik analisis data menggunakan beberapa perhitungan terhadap ketersediaan lahan pemakaman yang kemudian dianalisis secara deskriptif. Hasil penelitian menunjukkan bahwa TPU Semper memiliki tiga unit pemakaman yakni unit Islam, Kristen, dan Buddha. Dari jumlah Penduduk di Jakarta Utara berdasarkan ketiga agama tersebut $\pm 30.04 \%$ diprediksikan akan dimakamkan di TPU Semper. Lahan pemakaman yang tersisa hanya sebesar $15.660 \mathrm{~m}^{2}$. Bahwasanya dari luasan lahan yang tersedia hanya mampu menampung prediksi dari penduduk Jakarta Utara yang akan dimakamkan di TPU Semper hanya sebesar 4,5\%, dengan menampung sejumlah 5.786 jenazah. TPU Semper akan mengalami krisis lahan pemakaman karena jumlah lahan yang tersedia tidak mampu mencukupi kebutuhan penduduk. Pengelola mengupayakan adanya pemakaman tumpang susun jenazah, merencanakan adanya pembebasan lahan rawa, dan pembebasan lahan permukiman warga untuk mencukupi kebutuhan penduduk Jakarta Utara akan pemakaman.
\end{abstract}

Kata kunci: Ketersediaan lahan pemakaman, Jenazah, Tempat Pemakaman Umum (TPU) Semper

Abstract: This research aims to know about the availability of land for cemeteries at the Public Cemetery (TPU) Semper to fulfill the needs of burial grounds. The method used is a descriptive method with the survey approach. Obtaining other information by making informants in primary data collection.The informant is a TPU Semper manager. Data analysis technique that uses several calculations on the availability of burial land which is then analyzed descriptively at each question point. The results showed that TPU Semper had three funeral units, namely Islamic, Christian and Buddhist units. Of the total population in North Jakarta based on the three religions, \pm $30.04 \%$ are predicted to be buried in the Semper TPU. The remaining available burial ground is only 15,660 $\mathrm{m}^{2}$. That the available land area can only accommodate the predictions of North Jakarta residents who will be buried in the Semper TPU, only 4.5\%, by accommodating a total of 5,786 bodies. So in this case TPU Semper will experience a burial land crisis because the amount of available land is not able to meet the residents' needs for burials. The manager is working on an overlay funeral for bodies, planning for land acquisition for swamps, and for land acquisition for residents settlements to meet the needs of North Jakarta residents for funerals

Keywords: Burial Land Availability, Corpses, Semper Public Cemetery 


\section{A. PENDAHULUAN}

Setiap manusia yang lahir dimuka bumi ini pasti suatu saat akan mengalami yang namanya kematian. Ketika manusia mengalami kematian maka kegiatan yang dilakukan secara umum oleh masyarakat adalah proses pemakaman. Pemakaman berasal dari kata Makam, yang artinya adalah tempat tinggal, kediaman, bersemayam yang merupakan tempat persinggahan terakhir manusia yang sudah meninggal dunia dan kuburan adalah tanah tempat menguburkan mayat (Poerwodarminto, 1993 dalam Mularsih 2009:49). Tempat Pemakaman Umum merupakan bagian dari Ruang Terbuka Hijau Publik Kota Undang - Undang Perencanaan Ruang (UUPR) Nomor 24 Tahun 1992 Pasal 29. Sehingga Tempat Pemakaman Umum tidak lagi terkesan menyeramkan bagi masyarakat. Kebutuhan ruang terbuka menjadi kewajiban bagi pemerintahan untuk dapat memenuhi. Masalah yang ditemui di setiap negara termasuk Indonesia adalah kebutuhan akan ruang yang semakin menyempit khususnya untuk Pemakaman.

Menurut pengamat tata kota Universitas Trisakti Nirwono Joga mengatakan DKI Jakarta pada tahun 2018 hingga pertengahan tahun 2019 lahan pemakaman tercatat, sebanyak 385,5 Ha lahan sudah dipakai, sebanyak 31,4 Ha lahan siap pakai, dan sisanya
181,6 Ha merupakan lahan belum siap pakai. Nirwono Joga juga mengungkapkan diasumsikan jika kebutuhan lahan makam 3,75 $\mathrm{m}^{2} /$ petak makam dengan jumlah layanan kematian rata-rata 100 orang/hari, artinya dibutuhkan lahan $20 \mathrm{Ha} /$ tahun (Pratama, 2019). Diprediksikan masa pakai lahan mampu bertahan \pm 2 tahun kedepan sebagai lahan pemakaman Kondisi krisis lahan pemakaman pun sudah mulai dirasakan pada tahun 2019.

Berangkat dari permasalahan diatas bahwa DKI Jakarta mengalami krisis akan lahan pemakaman umum. Salah satu kota administrasi di DKI Jakarta yang mengalami krisis akan lahan pemakaman umum adalah Jakarta Utara. Luas lahan pemakaman umum yang tersisa di Jakarta Utara sebesar 713.437 $\mathrm{m}^{2}$, dan kebutuhan lahan pemakaman yang dipakai untuk menguburkan seluruh jenazah setiap tahunnya di seluruh Tempat Pemakaman Umum Jakarta Utara yakni sebesar $68.059 \mathrm{~m}^{2}$. Maka prediksi masa masa pakai lahan pemakaman mencapai titik terjenuhnya yakni \pm bertahan hingga 10 tahun 4 bulan ke depan.

Berangkat dari permasalahan diatas, terdapat Tempat Pemakaman Umum terbesar di Jakarta Utara yakni Tempat Pemakaman Umum (TPU) Semper. TPU Semper memiliki luas wilayah sebesar $575.660 \mathrm{~m}^{2}$ atau 57,566 
$\mathrm{Ha}$ (Dinas Kependudukan dan Pencatatan Sipil DKI Jakarta 2019). TPU Semper sering mengalami masalah berupa banjir, sebanyak 90 ribu petak makam terendam banjir ketika terjadi hujan dengan intensitas tinggi (Utama, 2018. Selain itu TPU Semper juga mengalami kepadatan pemakaman, karena luas lahan pemakaman yang ada sudah terisi \pm 100.000 petak makam. Luas lahan yang tersisa tidak semuanya dapat dijadikan lahan siap pakai untuk pemakaman. Terdapat luasan lahan pemakaman belum siap pakai yang dikarenakan permasalahan secara fisik maupun permasalahan sosial yang kerap terjadi di TPU semper.

Terbatasnya jumlah pemakaman yang ada tidak berbanding dengan kebutuhan pemakaman yang lebih besar dapat menimbulkan kepadatan tinggi pada pemakaman itu sendiri sehingga menimbulkan krisis lahan pemakaman tempat pemakaman umum merupakan jenis pemanfaatan lahan yang bersifat LULU (Locally Unwanted Land Use) yaitu lahan yang berfungsi untuk kegiatan yang mutlak diperlukan namun tidak diinginkan keberadaannya (Alam, 2012 dalam Angga, 2015). Melihat kondisi tersebut membuat penulis tertarik untuk mengetahui bagaimana ketersediaan lahan untuk pemakaman umum yang berada di Tempat Pemakaman Umum (TPU) Semper dapat menampung kebutuhan masyarakat akan lahan pemakaman. Selain itu upaya upaya apa saja yang dilakukan oleh pengelola TPU Semper dalam menghadapi keterbatasan lahan Pemakaman yang didasarkan pada daya tampung dan sistem yang berlaku.

\section{B. METODE}

Penelitian ini bertujuan untuk mengetahui tentang Ketersediaan Lahan Untuk Tempat Pemakaman Umum di Tempat Pemakaman Umum (TPU) Semper. Berdasarkan ketersediaan itu akan diketahui masa pakai lahan pemakaman mampu bertahan dalam jangka waktu tertentu habis pakai untuk memenuhi kebutuhan masyarakat akan penggunaan lahan pemakaman.

Metode yang digunakan dalam penelitian ini adalah metode deskriptif dengan pendekatan survei. Memperoleh informasi lain dengan menjadikan informan (narasumber) dalam pengumpulan data primer. Informan tersebut adalah Pengelola TPU Semper. Teknik analisis data yang digunakan penelitian ini mengacu pada perhitungan menurut (Amalia, 2016) terkait ketersediaan Lahan Pemakaman Umum, berikut ini macam - macam perhitungannya:

\section{Luas Lahan Pemakaman Tersisa}

Ketesediaan Lahan Pemakaman diketahui dengan cara menghitung luas lahan pemakaman keseluruhan dikurangi dengan luas lahan pemakaman yang telah 
digunakan atau terpakai. Berikut rumus perhitungannya:

$$
L T s=L K S-L T
$$

Keterangan

LTs : Luas Lahan Pemakaman Tersisa $\left(m^{2}\right)$

LKs:Luas Lahan Pemakaman Keseluruhan $\left(\mathrm{m}^{2}\right)$

LTp: Luas Lahan Pemakaman Terpakai $\left(m^{2}\right)$

\section{Kebutuhan Lahan Pemakaman}

Kebutuhan lahan pemakaman secara keseluruhan diketahui dengan cara mengalikan rata - rata angka kematian jenazah per tahun dengan luas petak makam yang dibutuhkan sesuai dengan aturan Pemerintah yakni $2 \mathrm{~m}^{2} /$ jenazah atau $3,75 \mathrm{~m}^{2} /$ jenazah. Berikut ini rumus perhitungannya:

$$
K L P=R A K \times L M
$$

Keterangan:

KLP : Kebutuhan lahan pemakaman ( $m^{2} /$ tahun)

RAK : Rata-rata Angka Kematian (jenazah/tahun)

LM : Luas petak makam yang dibutuhkan ( $2 \mathrm{~m}^{2} /$ jenazah $) /$ (3,75m²/jenazah)

\section{Daya Tampung Jenazah}

Daya tampung jenazah dapa dihitung pertama denga daya tampung tanpa tumpang susun jenazah dalam artian menggali lahan baru untuk petak makam. Untuk menghitungnya lahan pemakaman yang tersisa dibandingkan dengan luas petak makam yang dibutuhkan sesuai dengan aturan yakni $2 \mathrm{~m}^{2} /$ jenazah atau $3,75 \mathrm{~m}^{2} /$ jenazah. Berikut rumus perhitungannya:

$$
D T a=L T s / L M
$$

Keterangan:

DTa : Daya Tampung tanpa tumpang susun (jenazah)

LTs : Luas Lahan Pemakaman Tersisa

LM : Luas petak makam yang dibutuhkan (2m2/jenazah) / (3,75m2/jenazah)

Dari hasil perhitungan daya tampung tanpa tumpang susun jenazah (DTa) dapat diketahui prediksi masa pakai lahan pemakaman tanpa tumpang susun jenazah atau sampai titik terjenuh lahan tersebut dapat menampung jenazah dalam kurun waktu tahun tertentu. Hal ini dilakukan dengan membandingkan rata rata angka kematian jenazah per tahun dengan hasil dari daya tampung jenazah tanpa tumpang susun jenazah Berikut rumus perhitungannya:

$$
\mathrm{PMPa}=\boldsymbol{D T} \boldsymbol{a} / \mathrm{RAK}
$$

Keterangan:

PMPa : Prediksi Masa Pakai tanpa tumpang susun jenazah (tahun)

DTa : Daya Tampung tanpa tumpang susun (jenazah)

RAK: Rata - rata angka kematian (jenazah/tahun)

Daya tampung jenazah dengan tumpang susun jenazah dapat diketahui dengan melihat jumlah petak makam 
yang ada dan daya tampung tanpa tumpang susun jenazah kemudian dianalisis berdasarkan fakta kemudian dapat diprediksikan. Dari hasil perhitungan daya tampung dengan tumpang susun jenazah (DTb) dapat diketahui prediksi masa pakai lahan pemakaman dengan tumpang susun jenazah. Hal ini dilakukan dengan cara rata - rata angka kematian jenazah per tahun dibandingkan dengan hasil perhitungan daya tampung jenazah dengan tumpang susun jenazah. Berikut rumus perhitungannya:

\section{$\mathbf{P M P b}=\mathbf{D T b} / \mathrm{RAK}$}

Keterangan:

$\mathrm{PMPb}$ : Prediksi Masa Pakai tanpa tumpang susun jenazah (tahun)

DTb : Daya Tampung tanpa tumpang susun (jenazah)

RAK :Rata - rata angka kematian (jenazah/tahun)

Setelah data tersebut diperoleh hasil perhitungan data dianalisis secara deskriptif pada setiap perhitungan di Tempat Pemakaman Umum tersebut. Teknik analisis selanjutnya, data hasil wawancara dengan informan diperoleh kemudian dianalisis secara deskriptif pada setiap poin pertanyaan serta analisis secara kolektif untuk mengetahui upaya upaya yang dilakukan pengelola TPU dalam menghadapi ketersediaan lahan pemakaman yang semakin berkurang di TPU Semper kemudian disajikan dalam bentuk kalimat dan dipresentasikan.
Secara keseluruhan hasil data penelitian akan dianalisis berdasarkan pada Peta gambaran ketersediaan lahan untuk pemakaman di Tempat Pemakaman Umum (TPU) Semper secara lebih luas.

\section{HASIL DAN PEMBAHASAN}

Tempat Pemakaman Umum (TPU) Semper merupakan TPU Terbesar yang berada di Kota Administrasi Jakarta Utara, dan beralamatkan di Jl. Budi Dharma No. 01 Kelurahan Semper Timur Kecamatan Cilincing, Jakarta Utara. Pada Tahun 1984 Tempat Pemakaman ini secara resmi dibuka dan digunakan untuk umum dibawah pengelolaan Pemerintahan Dinas Pertamanan dan Hutan Kota DKI Jakarta. Peta lokasi TPU Semper dapat dilihat secara lebih jelas pada Gambar 1.

Luas lahan Tempat Pemakaman Umum (TPU) Semper sebesar 575.660 $\mathrm{m}^{2}$. Berdasarkan luas lahan tersebut sebanyak $475.193 \mathrm{~m}^{2}$ telah digunakan untuk pemakaman dan sebanyak 100.467 $\mathrm{m}^{2}$ lahan digunakan untuk sarana dan prasarana. Disekitar TPU Semper terdapat lahan berupa rawa sebesar 8000 $\mathrm{m}^{2}$, dan lahan rawa ini Secara keseluruhan luas lahan TPU Semper sebesar $583.660 \mathrm{~m}^{2}$. Luasan lahan di TPU Semper yang sudah terpakai sebanyak $560.000 \mathrm{~m}^{2}$. 


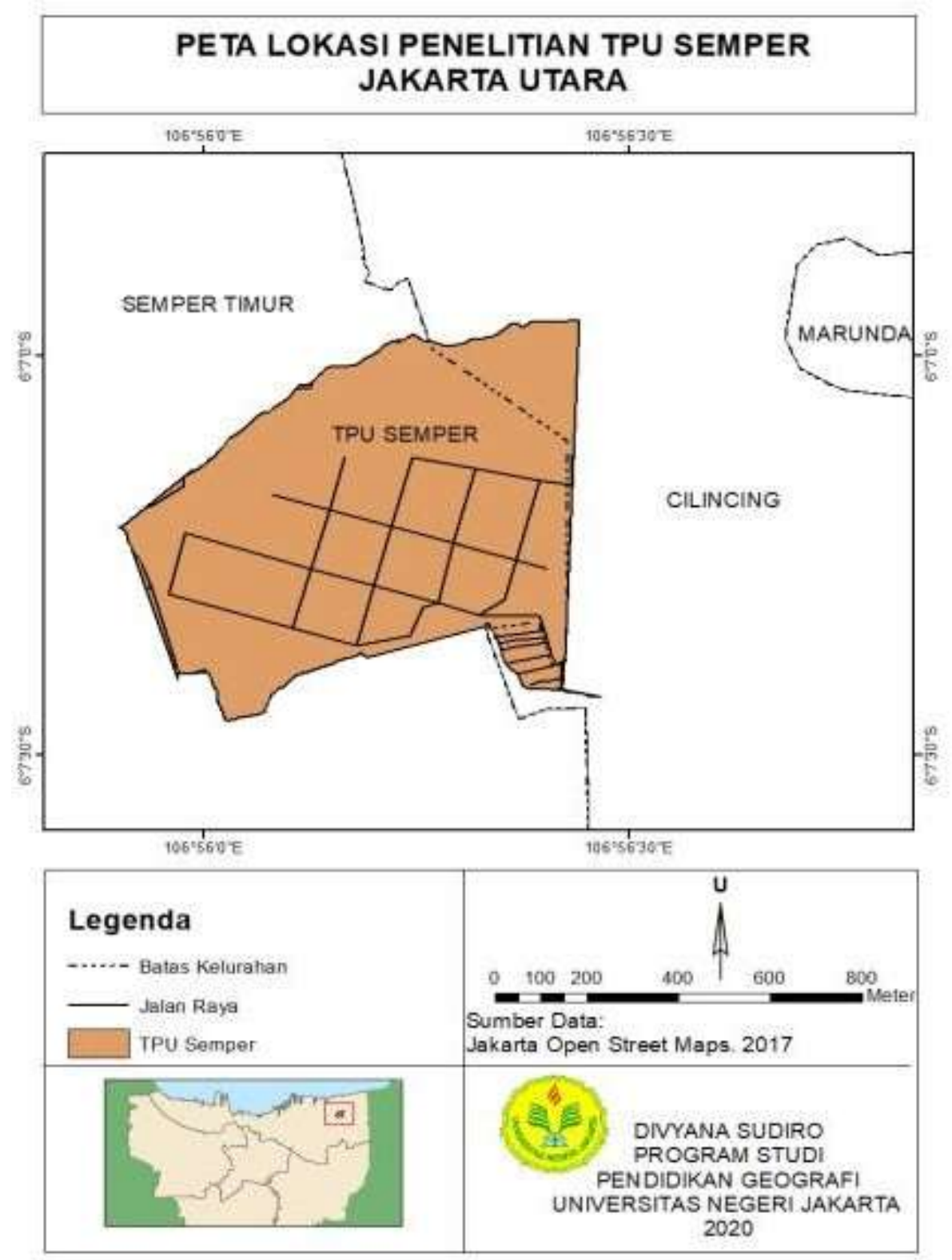

Gambar 1. Peta lokasi TPU Semper. Sumber: penelitian, 2020

TPU Semper memiliki 4 unit pemakaman yaitu pemakaman unit Islam, pemakaman unit Kristen, pemakaman unit Buddha, dan pemakaman khusus unit veteran. Unit pemakaman tersebut dibagi lagi kedalam 4 blok yaitu blok AA-I, AA-II, A-I, dan A-II. Secara keseluruhan dari blok tersebut terdiri dari 257 blad yang telah dibuka untuk petak pemakaman, setiap blad memiliki luas yang berbeda rata rata luasan nya $\pm 1.849 \mathrm{~m}^{2}$ dan dapat terisi antara 300 - 500 petak makam. TPU Semper telah diisi sebanyak 109.124 petak makam yang tersebar hampir diseluruh blad makam. 
Petak makam tersebut terdiri dari sebanyak 97.398 petak makam unit Islam, sebanyak 11.561 petak makam unit Kristen, dan sebanyak 165 petak makam unit Buddha. Luasan satu petak makam untuk unit Islam yakni seluas $\mathrm{m}^{2}$, dan luasan satu petak makam untuk Kisten maupun unit Buddha yakni seluas $3,75 \mathrm{~m}^{2}$.

TPU Semper menerapkan adanya sistem pemakaman dengan tumpang susun jenazah. Tumpang susun jenazah yang dilakukan yakni dengan menumpuk jenazah lama dibagian pundak dari si jenazah baru. Tumpang susun jenazah ini bisa dilakukan maksimal hingga menumpukkan 3 jenazah dalam satu petak makam. Pemakaman tumpang susun jenazah yang ada di TPU Semper jumlahnya \pm 20.000 makam yang telah ditumpangi dan tersebar diberbagai area. Dari jumlah tersebut, sebanyak 6.000 makam tumpang yang ada di unit Kristen dan 14.000 makam tumpang yang ada di unit Islam. Letak unit pemakaman berdasarkan agama dapat dilihat dengan lebih jelas pada Gambar 2.

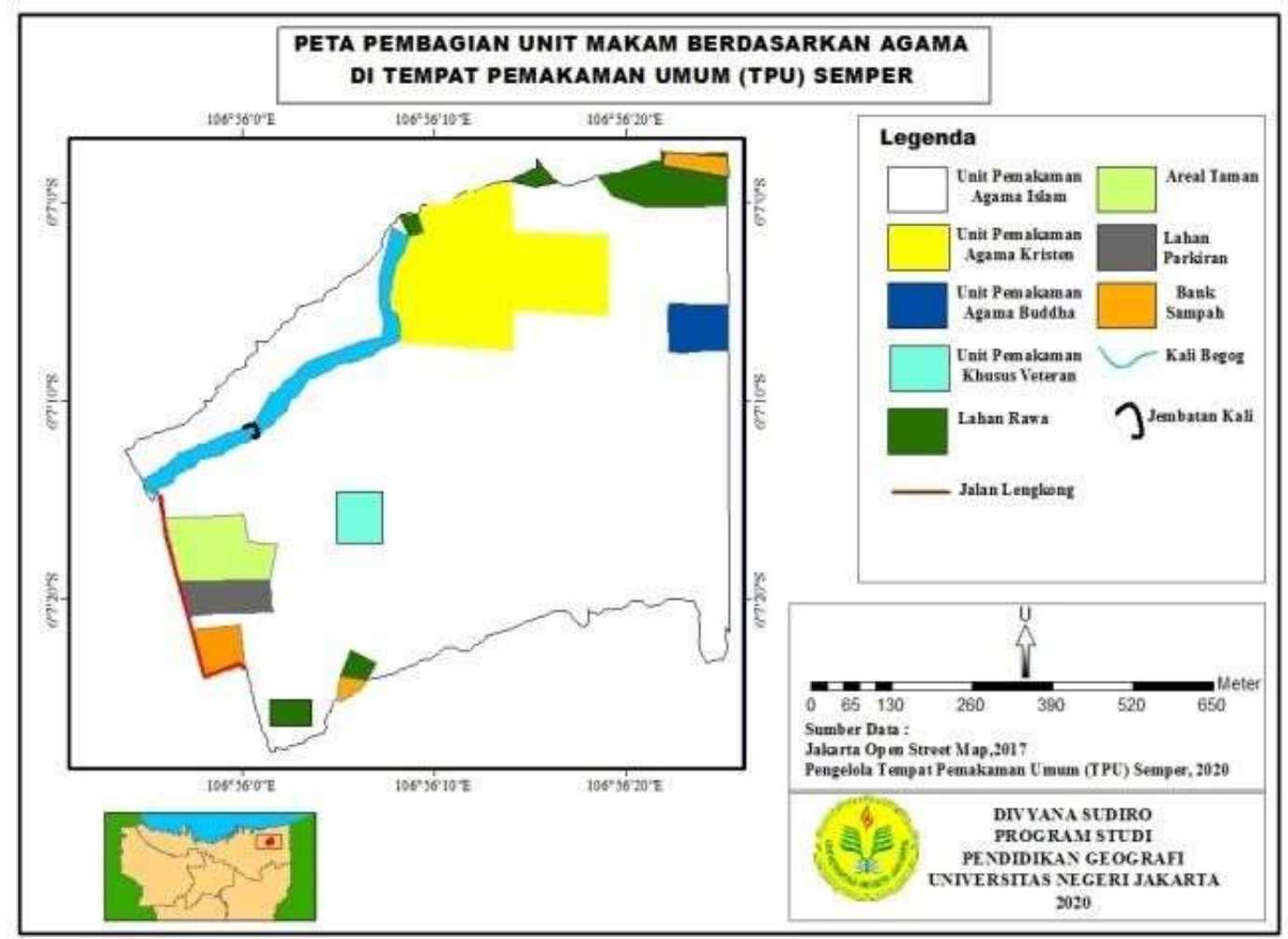

Gambar 2. Peta lokasi TPU Semper. Sumber: penelitian, 2020

Berdasarkan hasil wawancara dengan informan jenazah yang dimakamkan di TPU Semper berasal dari wilayah Jakarta Utara. Mayoritas berasal dari Kecamatan Cilincing dan Minoritas berasal dari Kecamatan Penjaringan. Kebutuhan pemakaman bagi penduduk Jakarta Utara diprediksikan sekitar 20\% 
penduduk Jakarta Utara yang beragama Islam kemungkinan dimakamkan di TPU Semper yakni \pm 281.633 jiwa, dengan kebutuhan lahan pemakaman sebesar $563.226 \mathrm{~m}^{2}$ atau $56,3226 \mathrm{Ha}$.

Diprediksikan sekitar $10 \%$ penduduk Jakarta Utara yang beragama Kristen kemungkinan dimakamkan di TPU Semper yakni \pm 25.151 jiwa, dengan kebutuhan lahan pemakaman sebesar 94.316,25 $\mathrm{m}^{2}$ atau 9,431625 Ha. Diprediksikan sekitar $0,04 \%$ penduduk Jakarta Utara yang beragama Buddha kemungkinan dimakamkan di TPU Semper yakni \pm 50 jiwa, dengan kebutuhan lahan pemakaman sebesar $187,5 \mathrm{~m}^{2}$. Kebutuhan akan pemakaman bagi Penduduk Budha di Jakarta Utara sedikit jumlahnya, hal ini dikarenakan mayoritas dari mereka melakukan pemakaman dengan cara mengkremasi jenazah yang kemudian abunya diarungi ke laut ataupun disimpan di Tempat Penyimpanan abu. Menurut ajaran agama Buddha perabuan atau kremasi menempati prioritas tertinggi dalam tradisi Buddhis.

Ketersediaan lahan pemakaman untuk unit Islam yakni tersisa sebesar $10.075 \mathrm{~m}^{2}$. Rata - rata angka kematian jenazah untuk unit Islam yang dikuburkan di TPU Semper per tahun yakni 4.280 jenazah. Kebutuhan akan lahan pemakaman pada unit Islam di TPU Semper per tahunnya sebesar 8.560 $\mathrm{m}^{2}$. Berdasarkan pada data tersebut bahwasanya unit Islam hanya mampu menampung kebutuhan penduduk Islam Jakarta Utara untuk pemakaman di TPU Semper sebesar $1,8 \%$, dari jumlah kebutuhan penduduk sebesar 563.226 $\mathrm{m}^{2}$. Daya tampung jenazah dengan menggali petak makam baru sebanyak 5.038 jenazah, dari jumlah prediksi penduduk Islam Jakarta Utara sebesar 281.633 jiwa. Prediksi masa pakai lahan pemakaman yang tersisa hanya mampu bertahan habis pakai \pm 1 tahun lagi yakni pada bulan Juli 2021.

Untuk meminimalisir penggunaan petak makam baru yang jumlahnya terbatas, dapat dilakukan pemakaman dengan tumpang susun jenazah. Saat ini unit Islam TPU Semper terdapat 14.000 petak makam yang sudah ditumpang susun dengan menumpukkan 2 jenazah. Maka dalam hal ini terdapat 83.398 petak makam yang belum di tumpang susun jenazah. Diprediksikan dari luasan lahan yang tersedia akan dapat menampung sebanyak 93.474 jenazah dengan pemakaman tumpang susun menumpukkan 2 jenazah, masa pakai lahan pemakamannya dapat bertahan hingga 21 tahun 8 bulan kedepan. Jika perhitungan ini terhitung pada bulan Juni 2020, maka masa pakai lahan pemakaman yang tersisa akan habis pada bulan Februari 2042.

Diprediksikan pula jika dengan menumpukkan 3 jenazah akan dapat menampung sebanyak 103.662 jenazah, 
masa pakai lahan pemakamannya dapat bertahan hingga 23 tahun 9 bulan kedepan. Jika perhitungan ini terhhitung pada bulan Juni 2020, maka masa pakai lahan pemakaman yang tersisa akan habis pada bulan Maret 2047.

Ketersediaan lahan pemakaman untuk unit Kristen yakni tersisa sebesar $2.506 \mathrm{~m}^{2}$. Rata - rata angka kematian jenazah untuk unit Kristen yang dikuburkan di TPU Semper per tahun yakni sebesar 420 jenazah. Kebutuhan akan lahan pemakaman pada unit Kristen di TPU Semper per tahunnya sebesar $1.575 \mathrm{~m}^{2}$. Berdasarkan pada data tersebut bahwasanya unit Kristen hanya mampu menampung kebutuhan penduduk Islam Jakarta Utara untuk pemakaman di TPU Semper sebesar 2,66\%, dari jumlah kebutuhan penduduk sebesar 94.316,25 $\mathrm{m}^{2}$. Daya tampung jenazah dengan menggali petak makam baru sebanyak 668 jenazah, dari jumlah prediksi penduduk Kristen Jakarta Utara sebesar 25.151 jiwa. Prediksi masa pakai lahan pemakaman yang tersisa hanya mampu \pm 1 tahun 6 bulan kedepan yakni pada bulan Desember 2021.

Unit Kristen juga menghendaki adanya pemakaman dengan tumpang susun jenazah untuk meminimalisir penggunaan petak makam baru. Saat ini unit Kristen TPU Semper terdapat 6.000 petak makam yang sudah ditumpang susun dengan menumpukkan 2 jenazah. Maka dalam hal ini terdapat 5.561 petak makam yang belum di tumpang susun jenazah. Diprediksikan dari luasan lahan yang tersedia akan dapat menampung sebanyak 6.897 jenazah dengan pemakaman tumpang susun menumpukkan 2 jenazah, masa pakai lahan pemakamannya dapat bertahan hingga 16 tahun 4 bulan kedepan. Jika perhitungan ini terhitung pada bulan Juni 2020, maka masa pakai lahan pemakaman yang tersisa akan habis pada bulan Oktober 2036. Diprediksikan pula jika dengan menumpukkan 3 jenazah akan dapat menampung sebanyak 12.229 jenazah, masa pakai lahan pemakamannya dapat bertahan hingga 29 tahun 11 bulan kedepan. Jika perhitungan ini terhhitung pada bulan Juni 2020, maka masa pakai lahan pemakaman yang tersisa akan habis pada bulan Juli 2052.

Ketersediaan lahan pemakaman untuk unit Buddha yakni tersisa sebesar $3.079 \mathrm{~m}^{2}$. Rata - rata angka kematian jenazah untuk unit Buddha yang dikuburkan di TPU Semper per tahun yakni sebesar 5 jenazah. Kebutuhan akan lahan pemakaman pada unit Buddha di TPU Semper per tahunnya sebesar 18,75 $\mathrm{m}^{2}$. Berdasarkan pada luasan tersebut bahwasanya sudah mampu menampung kebutuhan penduduk Buddha Jakarta Utara untuk pemakaman di TPU Semper yang hanya sebesar sebesar 187,5 $\mathrm{m}^{2}$. Jumlah tersebut menunjukkan bahwa unit Buddha di TPU Semper tidak mengalami krisis lahan akan 
pemakaman, karena mampu menampung kebutuhan penduduk Buddha di Jakarta Utara secara keseluruhan. Dalam hal ini luasan lahan yang tersisa pada unit Buddha jika sudah mencukupi kebutuhan penduduk nya, masih memiliki luas lahan yang tersisa sebesar $2.819,5 \mathrm{~m}^{2}$. Hal ini dikarenakan hanya sebesar $0,04 \%$ penduduk Jakarta Utara yang beragama Buddha kemungkinan dimakamkan di TPU Semper yakni \pm 50 jiwa. Maka kemungkinan masa habis pakai lahan pemakaman dapat menampung kebutuhan penduduk Buddha Jakarta utara mampu bertahan \pm 10 tahun lagi. Seperti pada penjelasan sebelumnya bahwasanya penduduk Buddha di Jakarta Utara untuk pemakaman mayoritas memilih untuk mengkremasi jenazah seperti pada anjuran yang diajarkan oleh agama mereka. untuk pemakaman.

Berdasarkan pada pejelasan penjelasan sebelumnya menunjukkan unit Islam dan unit Kristen di TPU Semper mengalami krisis lahan akan pemakaman, karena tidak mampu menampung kebutuhan penduduk Jakarta Utara secara keseluruhan. Selain itu bahwasanya luasan lahan yang tersisa lainnya pada unit Buddha dapat digunakan untuk unit lain yang memiliki kebutuhan pemakaman besar seperti unit Islam.

Berdasarkan deskripsi data hasil penelitian yang telah dipaparkan diatas, Ketersediaan lahan untuk pemakaman yang ada di TPU Semper jumlahnya terbatas. Hal ini dikarenakan telah terjadi kepadatan lahan pemakaman. Ketersediaan lahan pemakaman yang ada di Tempat Pemakaman Umum (TPU) Semper dapat dilihat dengan lebih jelas pada Gambar 3.

Berdasarkan hasil wawancara dengan pengelola adanya sistem daya tampung dengan tumpang susun jenazah sangat efektif dan sangat membantu untuk mengurangi pemakaian lahan petak makam baru. Ketika ada pengajuan untuk pemakaman baru oleh pihak pengelola selalu ditanyakan apakah sudah ada sanak keluarga atau kerabat yang dimakamkan di TPU ini agar mereka mau melakukan tumpang susun jenzah. Pengelola berharap agar setiap ahli waris yang akan melakukan pemakaman baru mau melakukan tumpang susun jenazah agar lahan pemakaman yang masih kosong dapat diisi oleh pemakaman baru yang ahli waris nya belum pernah melakukan penguburan di TPU Semper.

Permasalahan fisik yang kerap kali melanda di TPU Semper yakni banjir, seperti yang telah dijelaskan sebelumnya pada latar belakang. Untuk mengatasi masalah ini oleh pengelola TPU Semper dengan cara melakukan penyedotan air banjir tersebut menggunakan alkon sejenis pompa air. Kemudian air sisa banjir tersebut dibuang ke saluran air untuk mengurangi genangan air. Hal ini 
sangat efisien dilakukan jika hujan tidak turun terus menerus. Namun permasalahannya yang kerap terjadi, ketika air sudah selesai disedot menggunakan alkon pada malam harinya terjadi hujan lagi kemudian banjir lagi.
Saat ini belum ada cara lain yang dilakukan untuk mencegah atau mengurangi banjir yang terjadi.

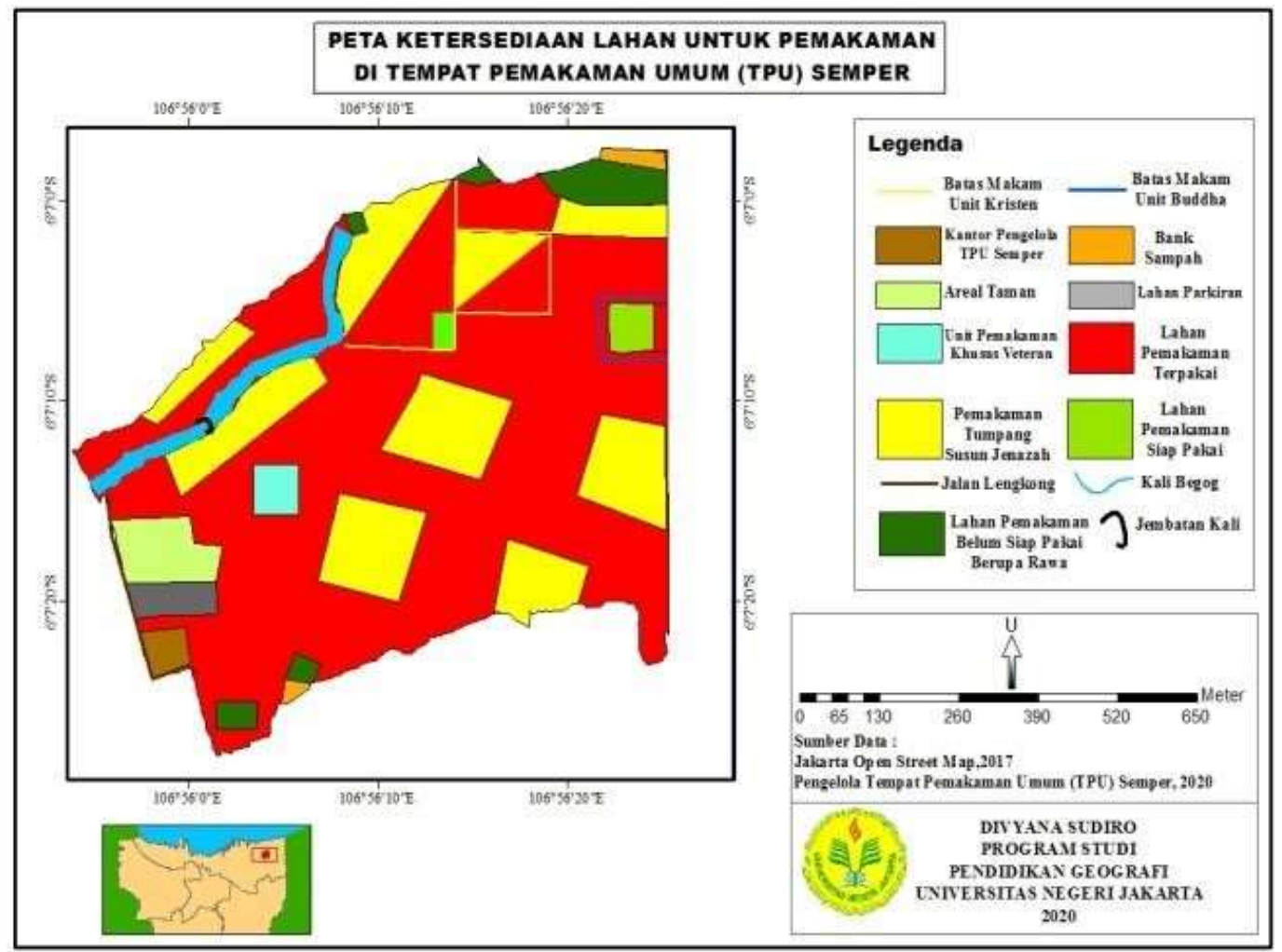

Gambar 3. Peta ketersediaan lahan untuk pemakaman. Sumber: penelitian, 2020

Permasalahan fisik selanjutnya yakni terdapatnya lubang - lubang tanah yang terjadi akibat permukaan tanahnya telah diambil. Ketika terjadi hujan lubang - lubang ini akan terendam dan tergenang oleh air hujan. Lubang - lubang tanah ini terbentuk akibat ulah warga sekitar yang melakukan pekerjaan secara ilegal. Warga sekitar dipekerjakan oleh ahli waris dari suatu makam untuk merapihkan makam secara pribadi. Dalam hal ini lambat laun permukaan tanah yang dikeruk oleh warga menimbulkan suatu lubang yang kecil kemudian seiring waktu lubang tersebut akan menjadi besar. Untuk mengatasi masalah lubang - lubang tanah ini, pengelola TPU Semper berencana akan mengisi lubang - lubang tanah tersebut dengan tanah baru sebagai penutup lapisan permukaan tanah. Rencana nya tanah - tanah tersebut berasal dari hasil pengerukan pembangunan seperti adanya pembangunan MRT, kemudian tanah 
hasil sisa pengerukan ini dibawa ke TPU Semper.

Permasalahan sosial yang terjadi di TPU Semper yakni terkendalanya kerjasama yang baik antara warga sekitar dan pengelola TPU Semper. Hal ini dikarenakan masyarakat sulit untuk diajak kerjasama dalam hal menjaga dan merawat petak makam. Kelakuan warga sekitar yang disebut dengan para pencari nafkah ini justru membuat makam makam yang ada di TPU semper menjadi tidak bagus, tidak rapih, dan tidak hijau.

Oleh karena itu dalam hal penjagaan dan keamanan di TPU Semper terdapat tim keamanan yang bernamakan PANGDAL (Pengamanan Dalam). Para PANGDAL ini bekerja mengamankan dan menjaga TPU Semper dengan cara berkeliling keseluruh luasan lahan TPU Semper menggunakan kendaraan yang telah disiapkan. Walaupun pihak pengelola telah mengerahkan PAMDAL tetap saja para pencari nafkah ini melakukan pekerjaan mereka dengan dalih telah dibayar oleh para ahli waris dari setiap makam yang mereka jaga. Pengelola TPU Semper mencoba untuk mensiasati upaya - upaya yang baik dalam hal penjagaan makam di TPU semper ini tanpa harus terlibat perselisihan dengan warga sekitar.

Isu adanya makam fiktif yang santer terdengar belakanagn ini pada Tempat Pemakaman Umum di DKI Jakarta memang pernah terjadi sekitar tahun 2016 - 2017. Faktanya di TPU Semper sendiri tidak pernah terjadi adanya makam fiktif. Hal ini karena berdasarkan wawancara dengan informan, bahwasanya untuk mendapatkan petak makam harus melalui prosedur yang sesuai tidak boleh memesan petak makam sebelum adanya surat keterangan resmi kematian dari si jenazah tersebut. Selain itu berdasarkan obrolan ringan antara penulis dengan perawat makam juga menjawab bahwa tidak adanya makam fiktif. Penulis juga mengamati di beberapa blad pada unit Islam, Kristen, dan Buddha tidak adanya lahan atau gundukan tanah yang hanya ditandai dengan batu maupun patok patok lain sebagai salah satu bukti adanya makam fikitf. Gundukan tanah yang ada semuanya telah diberi tanda berupa batu nisan maupun nisan kayu, dimana pada nisan tersebut terdapat keterangan dari si jenazah dan nomor sewa untuk petak makam yang dapat dilacak keberadaannya pada data. Maka dari itu di TPU Semper terbukti tidak pernah terjadi adanya makam fiktif berdasarkan pada penjelasan penjelasan tersebut.

Saat ini upaya yang telah dilakukan oleh Pengelola TPU Semper dalam menghadapi ketersediaan lahan makam yang jumlahnya sedikit yakni dengan mengoptimalkan penggunaan pemakaman sistem tumpang susun jenazah. Namun sistem tumpang susun 
jenazah ini tidak dapat dilakukan jika terdapat jenazah baru yang akan dimakamkan di TPU semper bukan meruapakan pihak keluarga ataupun ahli waris dari jenazah yang sudah lama dimakamkan disini. Untuk penggunaan petak makam baru pengelola mensiasati dengan menggunakan lahan yang berjarak diantara dua makam masih layak untuk digunakan.

Selain itu Pengelola TPU Semper merencenakan akan melakukan pembebasan lahan rawa menjadi lahan untuk pemakaman. Rencana yang akan dilakukan yakni dengan cara pengerukan lahan rawa tersebut dengan tanah untuk pemakaman yang didapatkan dari pihak MRT dan direncanakan akan dikerjakan pada bulan Oktober 2020. Adanya pembebasan lahan rawa tersebut maka akan dapat menampung minimal 2000 petak makan hingga maksimal 4000 petak makam siap pakai.

Pengelola TPU Semper bersama dengan Dinas Pertamanan dan Hutan Kota DKI Jakarta, berencana akan melakukan pembebasan lahan disekitar TPU Semper yang mana merupakan pemukiman warga yakni seluas $2 \mathrm{Ha}$ (hektar), pada bulan Oktober 2020. Namun karena pada tahun 2020 ini wilayah Indonesia khususnya DKI Jakarta dilanda pandemi virus Covid-19, maka rencana pembebasan lahan akan dilakukan pada tahun 2022. Hal ini dikarenakan anggaran pemerintah DKI
Jakarta yang mana untuk pembebasan lahan ini tergantikan untuk anggaran pemerian sembako. Oleh karena itu sambil menunggu rencana pembebasan lahan baru pengelola TPU Semper terus mengupayakan dan mengoptimalkan lahan pemakamaan yang tersisa dapat menjadi lahan siap pakai dan dapat mencukupi kebutuhan bagi Masyarakat Jakarta Utara dan khususnya bagi warga sekitar untuk memenuhi kebutuhan akan pemakaman.

\section{KESIMPULAN}

Berdasarkan data dan hasil analisis pada penelitian bahwasanya Tempat Pemakaman Umum (TPU) Semper mengalami kepadatan pemakaman. Luasan lahan yang tersedia terbagi kedalam tiga unit Pemakaman yang mana unit Islam memiliki ketersediaan lahan sekitar $64,4 \%$ yakni seluas $10.075 \mathrm{~m}^{2}$, Unit Kristen memiliki memiliki ketersediaan lahan sekitar $16 \%$ yakni seluas $2.506 \mathrm{~m}^{2}$, dan Unit Buddha memiliki memiliki ketersediaan lahan sekitar 19,6\% yakni seluas $3.079 \mathrm{~m}^{2}$. Dalam hal ini unit Islam dan unit Kristen akan mengalami krisis lahan pemakaman karena jumlah lahan yang tersedia tidak mampu untuk mencukupi kebutuhan penduduk akan pemakaman, selain itu prediksi masa pakai lahan untuk petak makam baru mampu bertahan hingga habis pakai \pm 1 tahun ke depan.

Kebutuhan akan petak makam secara umum lebih besar digunakan oleh 
penduduk beragama Kristen dan Buddha. Kebutuhan petak makam di TPU Semper didominasi oleh penduduk beragama Islam, karena rata - rata angka kematian jenazah pada unit Islam lebih banyak dibandingkan dengan unit Kristen dan Buddha. Tumpamg susun jenazah dilakukan dengan menumpukkan jenazah maksimal hingga tiga jenazah tetapi tidak pada waktu kematian yang bersamaan. Jika petak makam tersebut tidak diurus izin perpanjangan penggunaan tanah makam oleh pihak ahli waris setelah masa pakai berlaku hingga 3 tahun dan masa pengajuan paling lambat 3 bulan setelah masa izin perpanjangan berakhir, maka petak makam tersebut dapat digali kembali menjadi petak makam yang dapat diisi oleh jenazah baru. Pengelola mengupayakan adanya pemakaman tumpang susun jenazah, merencanakan adanya pembebasan lahan rawa, dan pembebasan lahan permukiman warga.

\section{DAFTAR PUSTAKA}

Aji A S, Suprayogi A, Wijaya A P. 2015. Analisis Kesesuaian Kawasan Peruntukan PemakamanUmum Baru Berbasis Sistem Informasi Geografis(Studi Kasus: Kecamatan Tembalang, Kota Semarang) http://semnas.big.go.id.Diakses pada tanggal 18 Desember 2019.

Amalaia, Ghea 2016. Ketersediaan Lahan Tempat Pemakaman Umum (TPU)Di Kota Surakarta. Jurnal. [online]. Yogyakarta : Universitas Gadjah Mada http://lib.geo.ugm.ac.id/. Diakses pada tanggal 11 Januari 2020.
Dinas Kependudukan dan Pencatatan Sipil DKI Jakarta. 2019. Data Makam DKI Jakarta. [online]. http://data.jakarta.go.id. Diakses pada tanggal 18 Oktober 2019.

Mularsih. 2009. Perubahan Alih Fungsi Lahan Taan Pemakaman Umum Menteng Pulo, Jakarta Selatam, Menurut Peraturan Daerah Khusus Ibukota Jakarta Nomor 6 Tahun 1999. Tesis. [online]. Depok : Uinversitas Indonesia (UI). Dari: http://lib.ui.ac.id . Diakses pada tanggal 31 Maret 2019.

Pratama. 2019. Manajemen Pemakaman di DKI Jakarta Perlu ditata. Artikel Berita. [online], Dari: https://www.medcom.id/. Diakses pada tanggal 20 Juni 2020.

Undang Undang Nomor 24 Tahun 1992 Tentang Penataan Ruang (UUPR) Pasal 24 (1). 1992. [online]. Dari: https://jdih.kemenkeu.go.id. Diakses tanggal 11 Mei 2019

Utama, Pradita. 2018. TPU Semper Di Jakut Kembali Terendam. Artikel Berita. [online]. Dari: https://m.detik.com/. Diakses pada tanggal 17 Januari 2020. 